\title{
全身性血管炎を呈した外耳道悪性黒色腫症例
}

\author{
札幌医科大学耳舆咽喉科学教室 (主任: 形浦昭克教授)

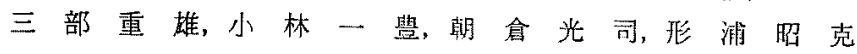

\section{A CASE OF MALIGNANT MELANOMA IN THE EXTERNAL AUDITORY CANAL FOLLOWED BY SYSTEMIC VASCULITIS}

\author{
SHIGEO SAMBE, M. D., KAZUTOYO KOBAYASHI, M. D., \\ KOJI ASAKURA, M. D. and AKIKATSU KATAURA, M. D. \\ Department of Otolaryngology, Sapporo Medical College, Sapporo
}

The malignant tumors of the ear are rare. Most of these are squamous cell carcinoma. We reported a 39-years-old woman of malignant melanoma in the right external auditory canal who suffered the generalized vasculitis during course.

After admission multiple coin lesions were revealed by a chest X-ray film which suspected pulumonary metastasis of melanoma, so a course of immunochemotherapy (Picibanyl, ACNU, DTIC and VCR) was given. The course after immunochemotherapy was improving satisfactory. The pulumonary lesions were getting better and general fatigability was lessened gradually. But on the 68th hospital day the patient experienced abdominal pain and bloody stool abruptly, and on the 80th hospital day the patient was died by DIC.

The autopsy revealed no melanoma cells in the any organs including the ear. But vasculitis was proven in the small intestine, colon, muscle, pulumonary tissues and also in the external auditory canal.

Key words: 悪性黑色腫, 全身性血管炎

A $88-0455-21301$

\section{I はじめに}

外耳道飞悪性腫湯が発生することは比校的稀であり， またその多くは扁平上皮由来である. 今回, 右外耳道淿 発生した慗性黒色隀症列で，その絓過中に全身の血管炎 を呈し，死飞至った興味深い症例を剖検する機会を得た のて, 臨床経過とともに文献的考察を含めて報告した。

\section{II 症例}

39歳, 女性, 教員

初彰: 昭和55年 9 月 3 日

主訴: 右耳漏

昭和54年11月23日, 有耳閉感出現したため某公立病院

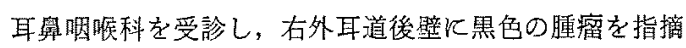
され，翌55年 1 月 10 日腫境摘出術を受けている。術後の 化学療法拉よび放射線治療については詳細は不明である が，外来的にクレスチン®の投与を受けていた．同年 8 月までは衙娞経過良好であったが，9月ごろから右耳漏 が出現してきたため9月3日当科初診となった。

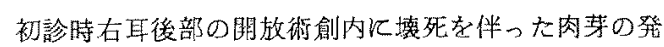
生がみられ，外等は道は狭小化し，彭膜は全欠損しており， 中耳郬は肉芽組織で充满していた，しかし，黒色の腫瘤 は認められなかった。左耳, 身腔拈よび咽喉頭には異常 所見が認められず，頸部りンパ節も触知されなかった。

頻回なる圾験切除几上っても炎症性肉莱のみであった 
表 1 一般臨床检查成績

\begin{tabular}{lclr}
\hline 1. 未梢血 & & & \\
赤血球 & 400 万 & 杆球 & $2 \%$ \\
ヘマトクリット & $35.5 \%$ & 分葉球 & $70 \%$ \\
血色素 & $11.4 \mathrm{~g} / \mathrm{d} l$ & リンバ球 & $18 \%$ \\
白血球数 & 10400 & 単球 & $5 \%$ \\
& & 好酸球 & $5 \%$
\end{tabular}

2. 血清蛋白分西

\begin{tabular}{lr} 
総蛋白 & \multicolumn{2}{c}{$7.9 \mathrm{~g} / \mathrm{d} l$} \\
Alb. & $47.9 \%$ \\
$\alpha_{1}$ & $4.5 \%$ \\
$\alpha_{2}$ & $13.1 \%$ \\
$\beta$ & $9.2 \%$ \\
$\gamma$ & $25.3 \%$
\end{tabular}

3. 刵機能, 血清電解質, 一般検尿, 止血機能, 便潜血反心：異常所胃なし

4. 血清反応その他

CRP 5t， ハプトブロビン $310 \mathrm{mg} / \mathrm{d} l$

5. 耳組菌蚞查：陰性

ため，外来的に経過を観察していたが，昭和55年11月よ り在耳漏が增加, 昭和56年 5 月ごろから舅计過多, 舅閉 および左媔部痛が出現するようとなり，同年10月26日突 然右顔面神経麻掉加出現したため10月28日当科入院とな った.

既往歴に21嵅時の肺絬核，24藏時の胆のう炎があり，

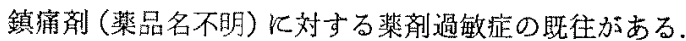
家族璴には特記すべきことはなかった。

\section{III 入院後経過および治療}

入院時現店：右耳後部開放創飞は，外来時上同様の肉

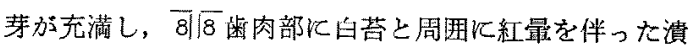

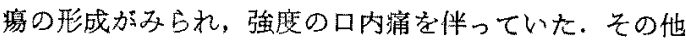
左耳, 舅副舆空, 咽喉頭飞は異常所見を認めなかった。

また右颜面神経麻瘦以外の他口脸神経症状はみられなか $っ$ た。

一般臨末椮查成績：䒾 1 飞示すごとく，末梢血白血球 数の增加, CRP 强陽性, $\gamma$ グロブリンの増加がみられ たが，它の他肝，腎機能検直に異常を認めなかった。

免疫学的検查成績: 表 2 に示すこととく，兔疫グロブリ ン $\operatorname{IgA}, \operatorname{IgG}$ の增加， ANF I+がみられたが，皮藤 テストは正常反応を示し，血中免疫被合体も正常值であ
表 2 免湾学的検查成綪

$\begin{array}{lc}\text { 1. 免疫グロブリン } \\ \operatorname{IgA} & 534 \mathrm{mg} / \mathrm{d} l \\ \mathrm{IgM} & 146 " \prime \\ \mathrm{IgG} & 2440 " \\ \mathrm{C} 3 & 94 " \prime \\ \mathrm{C} 4 & 54 "\end{array}$

2. 自己抗体

$\begin{array}{llrr}\mathrm{RA} & \pm & \mathrm{CHA} & \times 8 \\ \mathrm{~PB} & \times 14 & \mathrm{ANF} & 1+ \\ \text { 抗マイクロゾーム抗体 } & (-) \\ \text { 抗サイログロブリン抗体 } & (-) \\ \text { クームス試駺 } & \text { 直接 } & (-) \\ & \text { 間接 } & (-)\end{array}$

3. 度庵テスト

$\begin{array}{lc}\text { PPD } & 18 \times 15 \mathrm{~mm} \\ \text { SKSD } & 15 \times 11 \mathrm{~mm} \\ \text { Candida } & 5 \times 5 \mathrm{~mm} \\ \text { PHA } & 5 \times 5 / 24 \times 20 \mathrm{~mm} \\ \text { MUMPS } & 13 \times 11 \mathrm{~mm}\end{array}$

4. 血中兔疫複合体

2.8 $8 \mathrm{AHGEq} / \mathrm{m} l$ （正常 3.0以下）

り，他の自己抗体む检出されなかった。

X-線，CT 所見：側顽骨側面断層写真（图 1)にて塄 神経管垂直部の㓌影が不鮮明であり，顔面神経の障慧部 位と考えられた。市た耳小骨陰影委明膫で法な加った。 即頭骨 CT（図 2）では断層写真上同様に中耳〜乳突涺

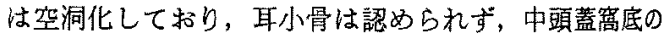

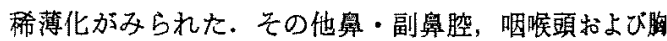
部X線写真上は異常所見はみられなかった。

その他の検查成績：聴力検查では右側は襲，左側正常 であり，骨，旰シンチグラムでも異常所見は㒛められな 加った。

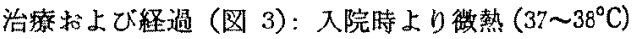
打上び全身倦急感が強くみられ，また右耳痛怙よび耳溜 も高度であった。第10病日ごるから高熱，また第15病日 ごるからは両䐂関節痛，咳嗽扣よび前胸部痛出現し，教 口蓋にも歯肉部之同栚の漬猉性病变が出現するようにな った，胸部X線写真（因 4）に括いて両側上肺野を中心 飞多発性の結節状陰殿が認められ，肺転移と考えられ た. 
発熱は抗生物質に反応せず持続するため, 副㴮皮犋ス テロイドホルモン（プレドニン®）を $20 \mathrm{mg} /$ 日 から投 与し, 下熱した時点で, Picibanyl 飞よる鬼疫療法と DTIC, ACNU, VCR 飞よる化学療法を開始した ${ }^{1 ”}$.

歯肉軟口蓋部の潰惶飞対してフォンギーソン®Kよる 含濑を行ったところ著明飞改善した. 図 3 亿示した兔度 化学療法 1 クール終了後, 全身状態著明汇改善, 小康 状热を保っていたが，第68病日ごろから下痢，下血を伴 万腹痛が出現, その後腹部全体の膨隆が出現, 腹部 X線 写真とてイレウス像を認めたため当院第 1 外科飞て試験 開腹を行ったところ回盲末端部より約 $30 \mathrm{~cm}$ そわたって 回腸側任多数の 小漬瘍性病変 括上び小隆起性病变を認 め, これを切除し，人工肚門を右下腹部に造設した. 第 79病日日になり，突然大量の消化管出血が出現し，DIC 状態となり翌第80病日目に死亡した。

\section{IV 病理組織学的所見}

右外耳道の原発巣は当科初診時にはすでにみられなか ったが, 前病院飞扔いて摘出した腫場組織飞扮けるH.E. 染色では（図 5), 外耳道皮層真皮内の 毛のう周辺沃メ ラニン色素を含えだ大小の腫嗢細胞が散在性に，また一 部ねは集積してみられたが, 異型度は高度ではないむの と考光られた.

剖検時，小腸は全長とわたり，内腔粘膜面に出血を伴 ったびらん, 小潰場性変化を呈し, 結腸飞も同様の变化が

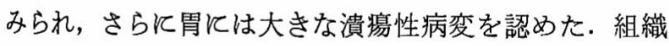
学的飞は小漬㥬飞接して, 周囲飞炎症性細胞浸潤を伴っ た肥厚した血管像がみられ(図 6), 血管炎の像之考光ら れ，消化管出血はこの上うな類似の病变加ら由来したも のと考兄られた. 肺は両側とも出血巣を伴った肺炎像を 呈していたが，胸部X線写真上みられた結節状の陰影飞 一致する部位には黒色の腫瘤は認められず，灰白色の結 節がみられ，H.E. 染色ではエオジン飞濃染する均一の 無構造の結節状を呈しており周囲淿多核球, 単核球の細 胞浸潤がみられた. 悪性黒色腫細胞は認められなかっ た. 同部位の Elastica Van Gieson 染色では, 弾性線 維の肥厚した血管像がみられ，これも血管炎と考えられ た (図 7). 外耳道, 乳突洞術創飞は表面飞柽度出血を 伴った肉芽組織で充満して叔り, この肉芽組織内㲹も血 管炎の像が認められた（図 8). その他腹部筇組織（図

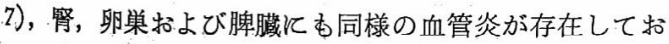
り，全身にわたって血管炎が存在したものと考光られ た. またいずれの部位に拈いても剖検時には悪性黒色腫

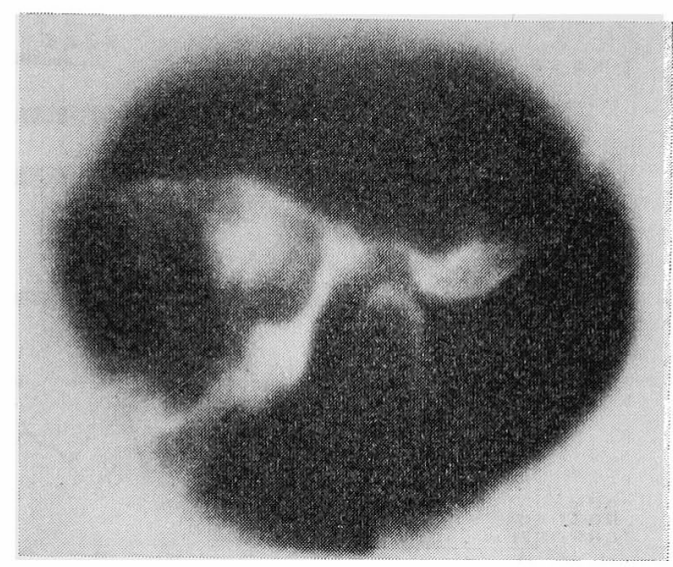

図 1 右側頭骨側面断層

顔面神経管垂直部飞括いて骨破壊像が 認められる.

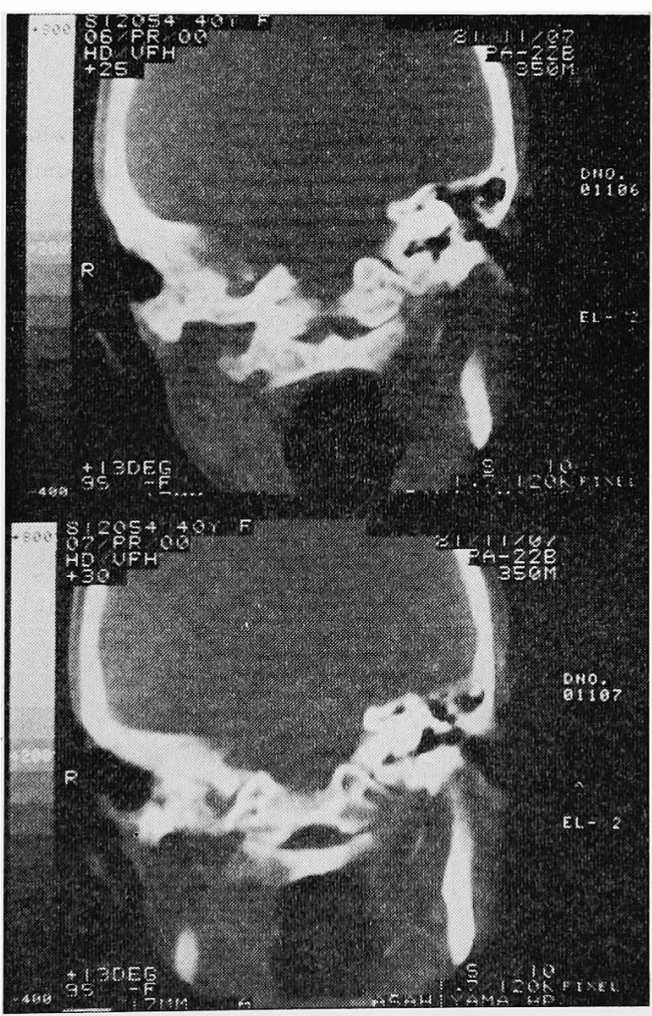

図 2 頭部 CT, 中耳腔〜乳突部の 空洞化 特よび中頭蓋窩底の希薄化が認めら れる。 


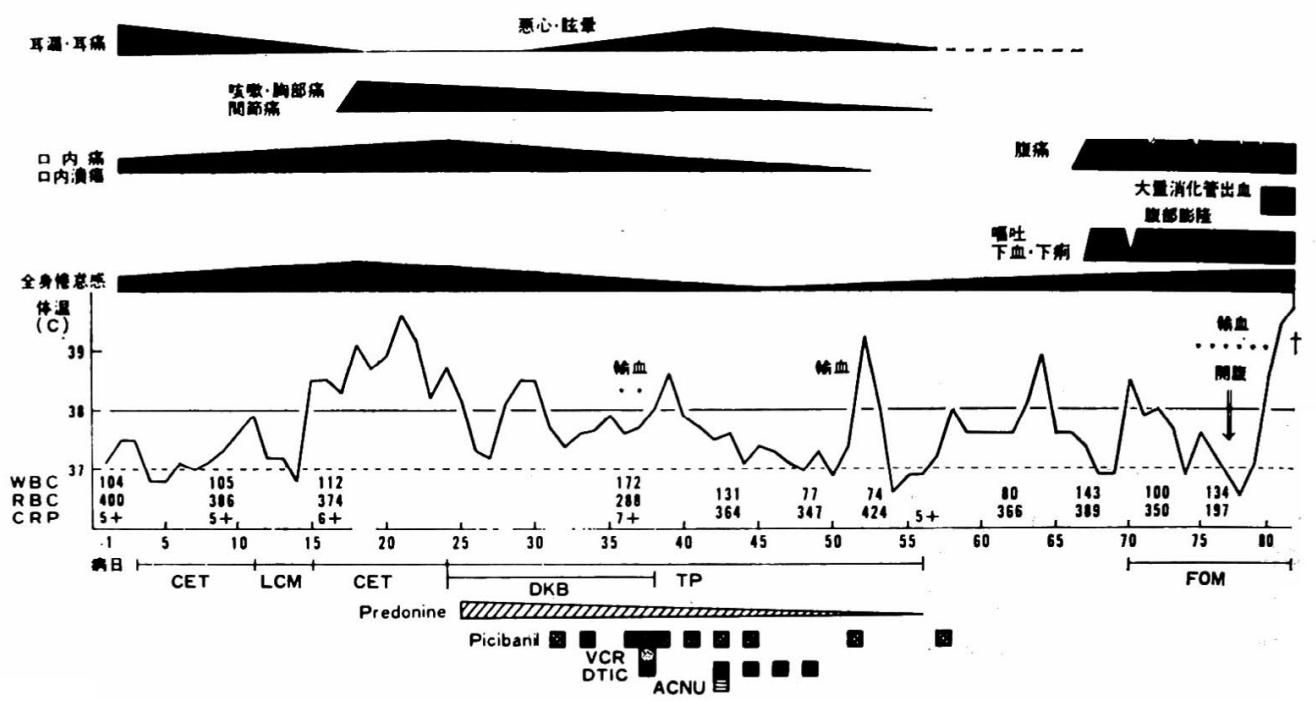

図 3 入院後経過および治療

CET: Cephalantin.

DKB: Dibekacin.

FOM: Fosfomycin.

VCR: Vincristin.

DTIC: Dimethyl-Triazeno-Imidazole-Carboxamide.

ACNU: Amino-Chloroethyl-Nitrous-Urea.

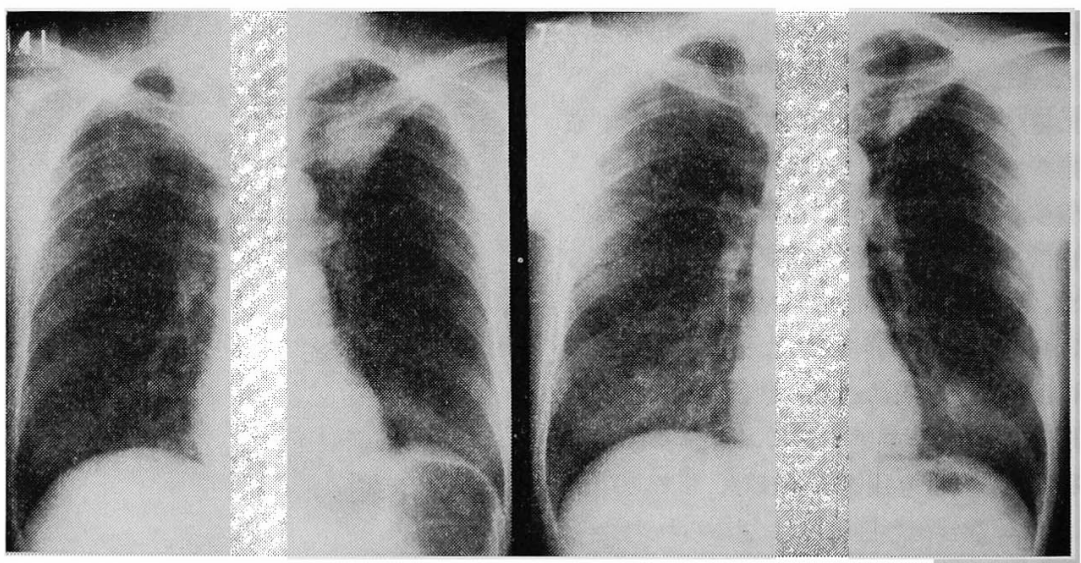

図 4 胸部X線写真
LCM: Lincomycin.

TP: Thiamphenicol. 

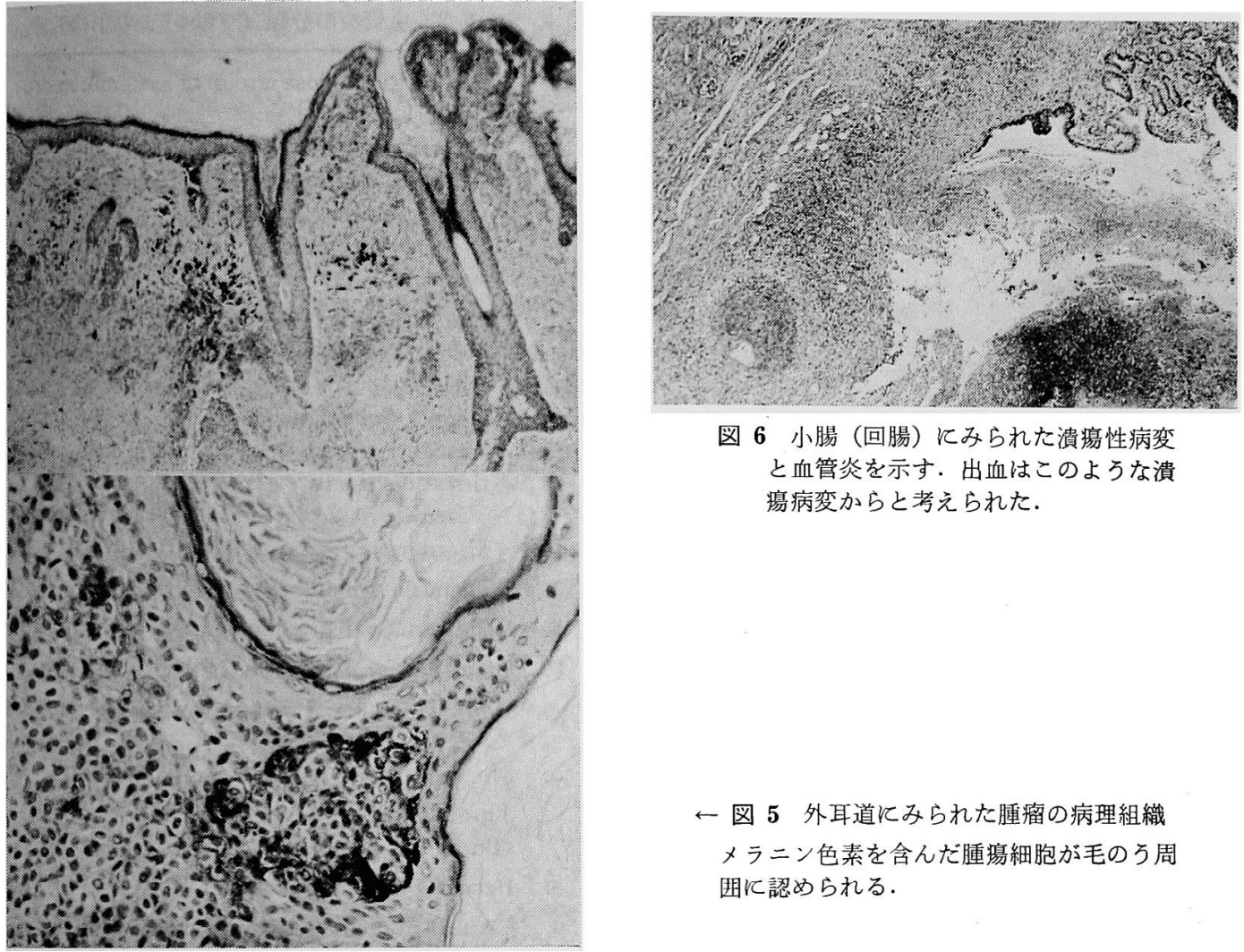
図 6 小腸（回腸）にみられた實瘍性病変 と血管炎を示す．出血はこのような潰 瘍病変からと考えられた。

\section{$\leftarrow$ 図 5 外耳道にみられた腫瘤の病理組織} メラニン色素を含んだ腫揚細胞が毛のう周 围に認められる。
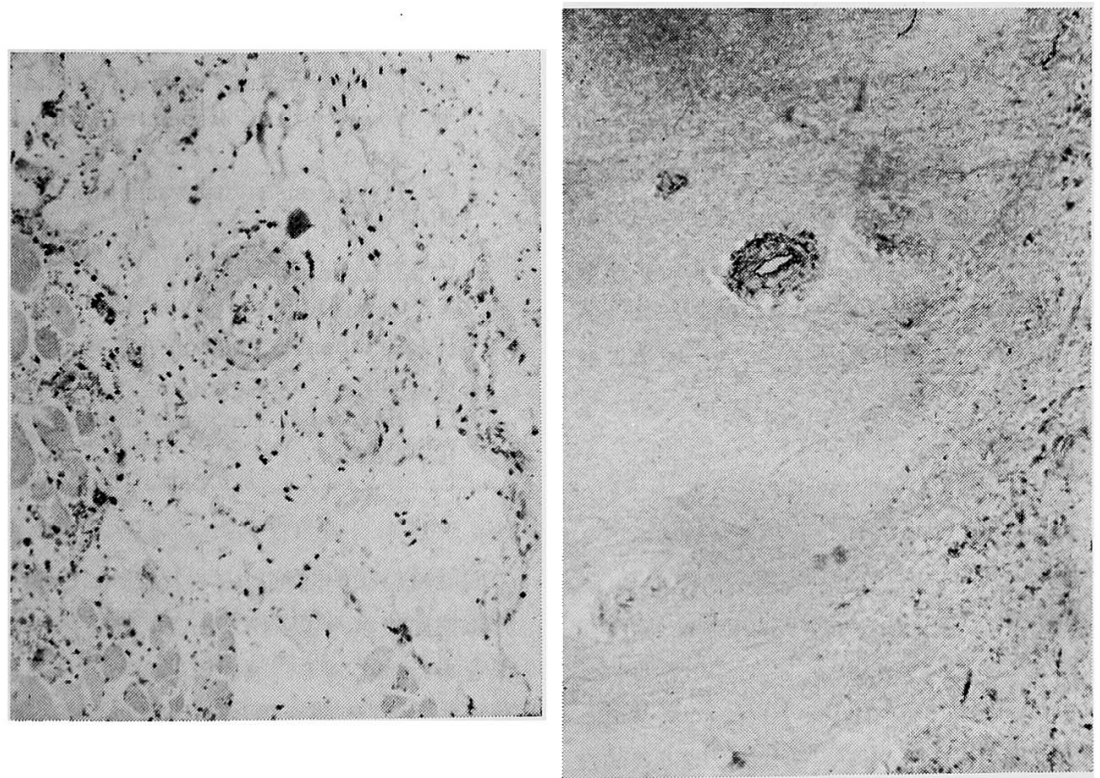

図 7

左側：腹部筋組織にみられた血管炎＼cjkstart右側：肺にみられた結節の Elastica Van Gieson 染色 


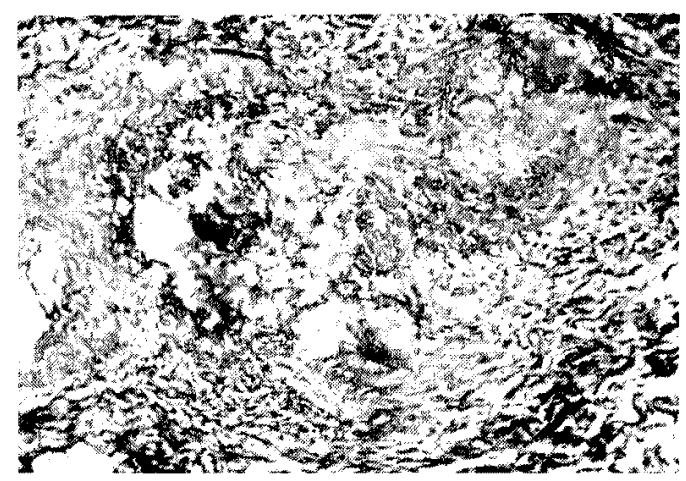

図8 外耳道化みられた肉芽組織内の血管炎

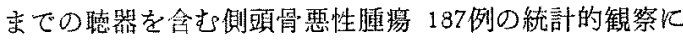
よ独は，わずか耳介発生した2例のみである。しかし 欧米に和いては涅器原発の悪性黒色近の発生は本邦飞比

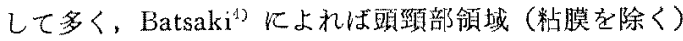
悪性黑色嗹のうち $13.1 \%$ \%珤器由来であるとされ，ま た Conley ${ }^{3} の 175$ 例の粘膜原発も念む䫒頸部瑟性黑色 連の集計でも $10.3 \%$ が悖器由来であるとされている。

血管炎ば血管の桊症と境死を特徴とする臨床的および 病理学的双方を包合した概念であり，これを分類すると

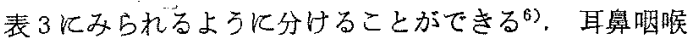
科領域でよく知られているのは Wegener's granulomatosis であり，頻度は少ないが，注意すべものとし $\tau$ Allergic angiitis and granulomatosis (ChurgStrauss Variant) "), Temporal arteritis がある. 前者

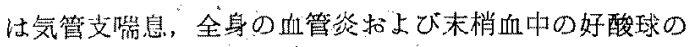

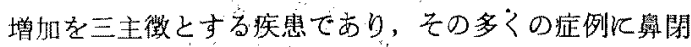
を主とする舜症状の合併がみられる。後者は頭頸部の動 脈，ことに側頭動脈の内膜の断裂，单核球扣よび巨細胞 の浸潤を特徽とし，䍜患血管の支配領域の激烈なる疼痛 を呈し，眼動脈の埸合，突然の失明汇至るのが特徴とさ れる.

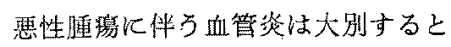

1) Systemic necrotizing Vasculitis

2) Granulomatous Vasculitis

3) Hypersensitivity Vasculitis および

4) Other systemic vasculitis associated with neoplasmas K分類される。

Systemic necrotizing vasculitis

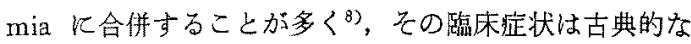
Polyarteritis nodosa (PAN) と変わることがなく，ま た Hairly cell leukemia 屯血管炎合併例と非合併例と
表 3 血管炎の分類（文献 6)より引用）

1. Polyarteritis nodosa group of systemic necrotizing vasculitis.

A. Classic polyarteritis nodosa

B. Allergic angiitis and granulomatosis (Churg-Strauss variant)

C. Systemic necrotizing vasculitis. "Overlap syndrome",

2. Hypersensitivity vasculitis

A. Serum sickness and serum sickness-like reactions

B. Henock-Schonlein purupura

C. Vasculitis associated with certain connective tissue disorders

D. Vasculitis associated with other primary disorders

3. Wegener's granulomatosis

4. Lymphomatoid granulomatosis

5. Giant cell arteritis
A. Temporal arteritis
B. Takayasu's arteritis

6. Mucocutaneous lymph node syndrome

7. Thromboangiitis obliterans (Buerger's disease)

8. Behcet's disease

9. Central nervous system vasculitis

10. Vasculitis associated with malignancies

A. Polyarteritis associated with malignancies

B. Granulomatous angiitis of the central nervous system associated with Hodkin's disease

C. Hypersensitivity vasculitis

D. Others

11. Miscellaneous
A. Cogan's syndrose
B. Erythema nodosum
C. Eales's disease
D. Erythema elevatum diutinum
E. Others

の䦔では特徽的变化はみられない。しかしその大部分に 脾脿摘出後 1 年以内に PAN が発定していることが骨

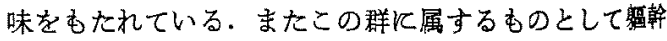
背部に生じた墨性黒色腫に 合併した systemic necrotizing vasculitis (Churg-Strauss variant) $の$ 症别加

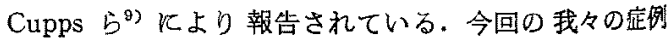
もこの群飞属するものと考えられる，Granulomatous 
vasculitis はホジキン病に合併することがあり ${ }^{10)}$ ，中枢 神経系の血管病変を主体とし，その多くが Varicella zoster virus の感染加認められて招り，ウイルス粒子は 証明されていないが，原因として重要な役割をはたして いるあのと考克られている、また興味あること恃，ホジ キン病の怪快ととも血管炎の症状む怪快していること である. Hypersensitivity vasculitis 㹥ホジキン病, 䎸 性リンパ隀招よび多発性骨髄腫に合併することがあり

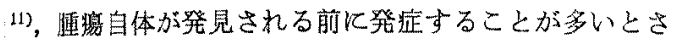
れている，その他の血管炎として，四肢末梢の動脈炎沉 よるレイノ一現象を呈する場合 ${ }^{12)}$ ，栄養血管の血管炎飞 よる神経炎を呈した場合などの報告がみられている。

血管炎の発生病理飞ついては不明な点が多いが，現在 のとこ万兔疫学的機序が最も考无られ，なかです免没複 、合体病としての発生機序がその主流を占めているように 思われる ${ }^{13)}$ すなかち，何らかの原因により生じた大量 の抗原烧对して可溶性の兔疫裸合体が血中に形成され，

糊内系飞て处理されない裸合体が血管壁飞沈着し，血小 板または好壏基球由来の vasoactive amines Kより血

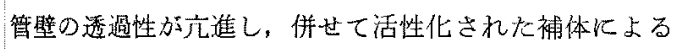
chemotactic factor により遊走してきた多核球由来の lysozomal enzyme により血管障害性が生ずるとするも のである.また他炕細胞性免疫の関与も考元られて和 り，感作リンパ球由来の lymphokine Kより macrophage の遊走が生し，これにより放出された lysozomal enzyme Kより 血管障害性が生ずるとされるるのであ る.

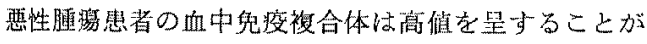
多いことが知られて招り，合併する血管炎の発生機序と

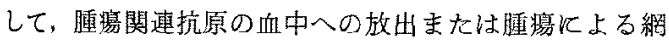
内系化対するブロック作用による免疫複合体の処理嘰序 の障害《よるむのが考党られている。

悪性黒色㹸と血管炎の合併例决の報告は桸であ り，Cupps `) らKよる1例のみであり，本邦ではその報 告例はみられない。

今回我々の経験した症例は血中免疫被合体阮 $2.8 \mu \mathrm{g}$ $\mathrm{AHC}_{\mathrm{Eq}} / \mathrm{m} l$ (正常 $3.0 \mu \mathrm{g} \mathrm{AHC} \mathrm{Eq} / \mathrm{m} l$ 以下) 之嵪值を呈 してはいなかったが，病理組織学的所見火上り全身性の 血管炎肪証明されて招り，恶性黒色腫と血管炎と間の密 接な関連性については必ずしも断定し得ないが，关の臨 床経過の推移から，相互化何らかの因果関係があるもの と推察された.

\section{$V$ 結 論}

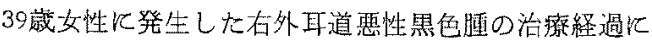

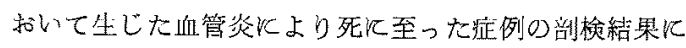

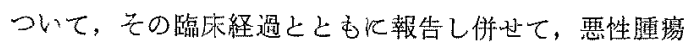
と血管炎の閉連性江ついて文献的飞考察し，恶性黑色随 と血管炎との間飞何らかの関連性があるものと推測され た.

\section{參考文献}

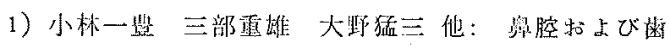

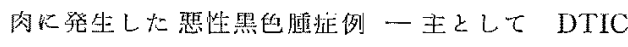
扣よび Me-CCNU 昨用療法について 耳舅臨床 $71: 1499-1507,1978$.

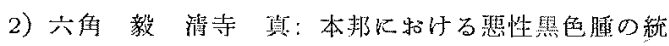

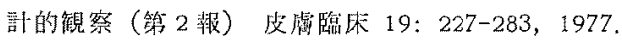

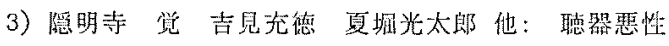

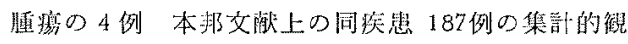
察 耳展 7: 206-217， 1964.

4) Batsakis JG: Melanomas (Cutaneous and Mucosal) of the Head and neck. Tumors of the Head and Neck. The Williams and Wilkins Company. 431-447, 1979.

5) Conley JJ and Pack GT: Melanoma of the External Ear. Cancer 21: 226-233, 1968.

6) Cupps TR and Fauci AS: Vasculitis and Neoplasm. Adv Internal Med 27: 116-122, 1982.

7) Olsen KD, Meel III $\mathrm{HB}$ and Deremee RA: Nasal Manifestations of Allergic Granulomatosis and Angiitis (Churg Strauss Syndrome). Otolaryngol Head and Neck Surg 88: 85-89, 1980.

8) Golomb HM, Catovsky D and Glode DW: Hairly Cell Leukemia. A Clinical Review Based on 71 Cases. Ann Internal Med 89: 677-683, 1978.

9) Cupps TR and Fauci AS: Neoplasm and Systemic Vasculitis: A Case Report. Arthritis Rheum 25: 475-477, 1982.

10) Nurick $S$, Blackwood $W$ and Mair WGP: Giant Cell Granulomataous Angiitis of the Central Nervous System. Brain 95: 133-142, 1922.

11) Sams WM Jr, Harville DD and Winkelmann RK: Necrotizing Vasculitis Associatid with Lethal Reticuloencothelial Diseases. Br J Derm 80: 
555-560, 1966.

12) Friedmann $S A$, Bienenstock $H$ and Richter $I H$ : Malignancy and Arteriopathy. A Report of Two Cases, Angiology 20: 136-142, 1969.

13) Fauci AS: The Spectrum of Vasculitis. Clinical, Pathology, Immunologic and Therpeutic Considerations. Ann Internal Med 89: 660-676, 1979.
橉を釉えるにあたり，御指尊御教授いたたいた本大学 成科学教室助教授神保孝一先生, 徫生短期大学部教授简

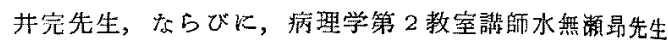

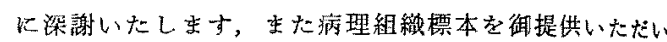
た古立曲版㾂院神田誠博士に感謝いたします。

（原稿受付炤和 59.9.3日）

別刷清求先 $\bar{T} 060$ 札覞市中央区丽1条西16丁目 札惧医料大学耳舅咽喉科学教室 三部重陫 